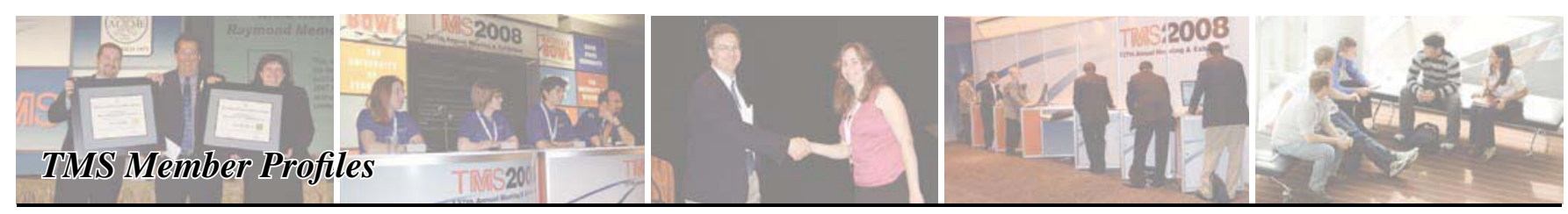

\title{
Meet a Member: Eric Taleff, Tourist of Japan's Metallurgical Treasures
}

\section{By Francine Garrone}

Circumscribed by the mountain chains of Kinkakuji-cho, Kita-Ku, Japan, sits a metallurgical treasure that has astounded Eric Taleff since he began traveling to Gunma-ken in the Kanto region on the island of Honshu. Partially covered in gold leaf, the Kinkaku-ji, or Golden Pavilion Temple, has brought metallurgists from across the globe-like Taleff-to examine its long metallurgical history and view its harmonious appearance that reflects in the pond that surrounds the temple on three sides (Figure 1).

Taleff, a professor and Charlotte Maer Patton Centennial Fellow in Engineering in the Department of Mechanical Engineering at the University of Texas at Austin, travels yearly to Japan not only to further his professional career, but also to spend time with his wife's family.

"As a mechanical metallurgist, it is especially interesting to visit Japan, a country steeped in a long history of metallurgical excellence," he said. "Some of the more easily appreciated metallurgical treasures include Kinkaku-ji and the Horyu-ji (Temple of Flourishing Law) treasures housed at the Tokyo National Museum."

The Horyu-ji treasures that Taleff speaks of are various gold and bronze metalwork dating back to the 7 th and 8 th centuries.

Taleff began traveling to Japan in 2005 to work with industrial as well as university colleagues. His family—wife, Yumiko; son, Michael; and daughter, Emily_have traveled along with him allowing for his children to spend time with their grandparents and become familiar with their heritage, language, and culture.

"The privilege of working with my colleagues in Japan is very meaningful to me," he said. "In particular, it is always an opportunity for me to learn from them. Together, we have shared ideas and knowledge to solve impor-

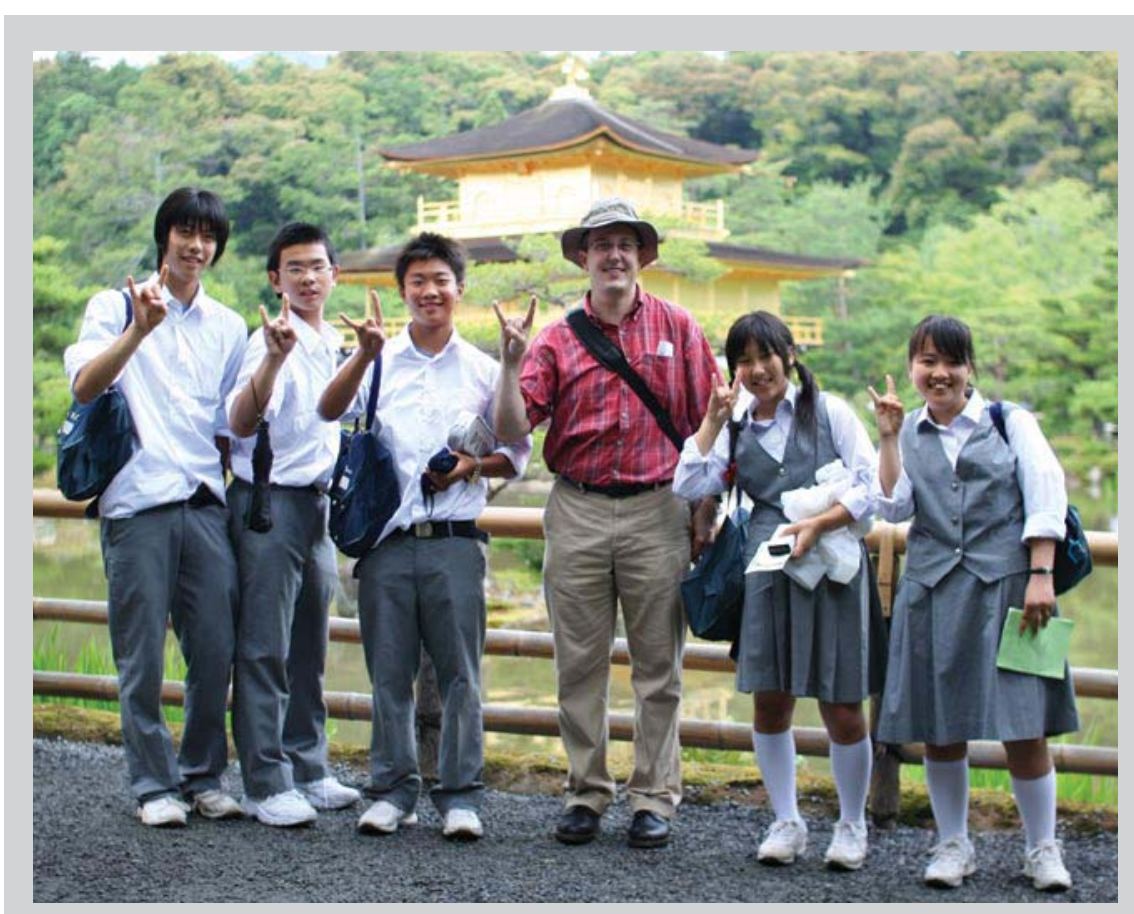

Figure 1. Eric Taleff and a group of local school children give the Texas Longhorn sign in front of Kinkaku-ji. Taleff had helped the children with English practice while in Japan.

tant technological problems and better serve our profession. It is professionally rewarding for me to have access to expertise not necessarily available in my home country and to learn from different ideas and completely different ways of looking at things."

Although Taleff's month-long trip is mainly consumed by work, he said he usually has a few days each year to "play the tourist," which he describes as "tremendous fun." Taleff said he enjoys learning about historical metallurgy from the Sakai region, where traditional techniques of fabricating cutlery are still preserved to this day.

In 2008, Taleff was able to visit Kinkaku-ji. Built in 1393, the Golden Pavilion Temple served as a retirement villa for Shogun Yoshimitsu Ashikaga. The Shogun had intended to cover the exterior of the pavilion with gold, but only managed to coat the ceiling of the third floor before his death. During the Onin War, Kinkaku-ji burned several times and again in 1950. The present temple structure dates back to 1955 . Today, both upper stories are covered in gold leaf, in accordance with Ashikaga's original intentions.

He may be well versed in its history, but Taleff admits he is far from proficient in Japan's language. "I have picked up just barely enough of the Japanese language to get into trouble, and to be able to travel a bit on my own," he said. "Each time I visit, I do pick up a bit more of the language. However, it is looking like I might reach retirement before I can become passably fluent in a short conversation." Taleff plans to continue his annual visits despite the language barrier.

Each month, JOM features a TMS member and his or her activities outside of the realm of materials science and engineering. To suggest a candidate for this feature, contact Francine Garrone, JOM news editor, at fgarrone@tms .org. 